\title{
Feasibility of structured light Plethysmography (SLP) in patients with coronavirus disease 2019 (COVID-19)
}

\author{
Natalie Simon ${ }^{1}$, Azhar Hussain ${ }^{2^{*}}$, Priyanka Kolvekar ${ }^{3}$ and Shyam Kolvekar ${ }^{2}$
}

\begin{abstract}
As a result of the COVID-19 pandemic, most institutions have changed the way patients are assessed or investigated. Using novel non-contact technology, it is possible to continuously monitor the lung function of peri-operative patients undergoing cardiothoracic procedures. Primarily, this results in increased patient surveillance, and therefore, safety. Many centres, globally, are starting to use structured light plethysmography (SLP) technology, providing a non-aerosol generating procedure in place of traditional spirometry. While more evidence is needed, our clinical usage; previous and on-going studies; demonstrate definite potential that SLP is a valuable tool.
\end{abstract}

Keywords: Coronavirus, Chest wall deformity

\section{Correspondence:}

The clinical manifestations of COVID-19 range from mild upper respiratory tract illnesses to progressive severe pneumonia, acute respiratory distress syndrome, multi-organ failure, and death. Measures to control the impact of the virus have affected job security, social contact and challenged health services, medical practices and policies. The health service has been radically mobilised to respond to the acute needs of patients infected with the virus at the same time as delivering scaled-back non-COVID-19 healthcare. In many surgical specialties, the management of perioperative patients has changed, with greater focus on remote triage through virtual consultations. However, pre-operative evaluation of surgical candidates still must happen, in person, at the clinic. One important aspect of pre-operative evaluation prior to thoracic surgery is pulmonary function testing (PFT), traditionally measured by conventional spirometry.

Understandably, concern has been raised that PFT represents a potential avenue for increased COVID-19

\footnotetext{
* Correspondence: azharhussain@nhs.net

Thoracic Surgery, Bart's Heart Centre, St Bartholomews Hospital, London, UK Full list of author information is available at the end of the article
}

transmission due to increased viral dissemination. The healthcare sector is calling upon novel technology to replace PFT with a non-aerosol-generating alternative.

Structured Light Plethysmography (SLP), delivered by PneumaCare Thora-3DI ${ }^{\mathrm{Tm}}$ systems, has been proposed as a novel, non-contact, non-invasive method of assessing lung function. SLP offers real-time regional respiratory function via movement of the chest wall. This detailed information is then translated into quantifiable pulmonary function outputs. SLP data has been used to optimize non-invasive ventilatory settings. The field has used SLP to successfully differentiate between the breathing patterns of healthy patients and those with COPD by mapping the thoracoabdominal displacement rate and accurately estimating inspiratory and expiratory flow [1]. The ability to continuously measure these parameters may contribute to the safe weaning of patients from ventilatory support. Additionally, we believe that SLP technology will allow clinicians to obtain measurements of breathing patterns that are closer to ecological conditions than those derived from spirometry measurements.

Our centre is currently trialling SLP in the work-up of pre-operative cardiothoracic patients. We have so far 
enrolled 20 patients in our pilot study comparing the feasibility of SLP measurements as parameters indicative for lung function. Our initial results demonstrated a correlation between the IE50 SLP (inspiratory to expiratory flow at $50 \%$ tidal volume) measurement and the forced expiratory volume in the first second of expiration $(p=$ $0.021, r=-0.62)$. We feel it is intuitive to use and, therefore, does not require trained technicians, resulting in increased patient throughput and lower costs to the department. Care efficiency also improves as the time-perappointment is reduced, benefitting patient wait times and increasing satisfaction. Importantly, SLP offers clinicians continuous measurement of mechanical chest wall displacement, a surrogate marker for fatigability and neuromuscular strength.

For the aforementioned reasons, we feel that SLP is a viable alternative to spirometry, especially in the current pandemic. Spirometry remains the gold-standard PFT, however, and the field would certainly benefit from studies evaluating the sensitivity, specificity and clinical validity of SLP in impairment detection, against goldstandard PFT.

\section{Abbreviations}

COVID-19: Coronavirus disease; SLP: Structure light plethysmography; PFT: Pulmonary function tests; COPD: Chronic obstructive pulmonary disease

\section{Acknowledgements}

Not applicable.

\section{Authors' contributions}

NS wrote the initial draft. All authors were involved in the concept and editing of the final version. The author(s) read and approved the final manuscript.

Funding

No funding was received for this.

Availability of data and materials

Not applicable.

\section{Declarations}

Ethics approval and consent to participate

Ethics approval was waived.

Consent for publication

Not applicable.

\section{Competing interests}

The authors declare they have no competing interests.

\section{Author details}

${ }^{1}$ Cambridge University NHS Foundation Trust, Cambridge, UK. ${ }^{2}$ Thoracic Surgery, Bart's Heart Centre, St Bartholomews Hospital, London, UK.

${ }^{3}$ University of Warwick, Coventry, UK.

Received: 11 January 2021 Accepted: 18 February 2021

Published online: 03 March 2021

\section{Reference}

1. Motamedi-Fakhr S, lles R, Barney A, De Boer W, Conlon J, Khalid A, Wilson $\mathrm{RC}$. Evaluation of the agreement of tidal breathing parameters measures simultaneously using pneumotachography and structured light plethysmography. Physiol Rep. 2017;5(3):e13124. https://doi.org/10.14814/ phy2.13124.

\section{Publisher's Note}

Springer Nature remains neutral with regard to jurisdictional claims in published maps and institutional affiliations.
Ready to submit your research? Choose BMC and benefit from:

- fast, convenient online submission

- thorough peer review by experienced researchers in your field

- rapid publication on acceptance

- support for research data, including large and complex data types

- gold Open Access which fosters wider collaboration and increased citations

- maximum visibility for your research: over $100 \mathrm{M}$ website views per year

At BMC, research is always in progress.

Learn more biomedcentral.com/submissions 